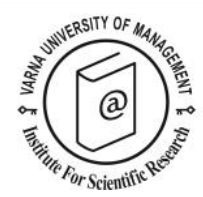

\title{
Revisiting the quality-value-satisfaction-loyalty chain for corporate customers in the travel agency sector
}

\author{
Juan C. Granados ${ }^{1}$ Leonor M. Pérez ${ }^{2 *}$, José A. Pedraza-Rodríguez ${ }^{3}$ and \\ Martina G. Gallarza ${ }^{4}$
}

\footnotetext{
${ }^{1}$ Department of Business Management, University of Córdoba, Spain. E-mail: jcgranados@uco.es

${ }^{2}$ Department of Business Management, University of Córdoba, C/ Adarve, 30, 14001 Córdoba, Spain. E-mail: lperez@uco.es

3 Department of Business Management, University of Córdoba, Spain. E-mail: japedraza@uco.es

4 Department of Marketing and Market Research, Universitat de València, Spain. E-mail: martina.gallarza@uv.es

* Corresponding author
}

\begin{abstract}
Most traditional travel agencies offer their services to corporate clients, although literature focuses on end customers. This paper addresses this research gap but also aims at bridging the gap between $\mathrm{B}_{2} \mathrm{C}$ and $\mathrm{B}_{2} \mathrm{~B}$ literature. Specifically, the authors revisit the Quality-Value-Satisfaction-Loyalty chain, a well-established postulate from the $\mathrm{B}_{2} \mathrm{C}$ literature in tourism, but adding Trust and Commitment as mediating variables between Satisfaction and Loyalty to adapt the chain to the B2B context. Using PLS-SEM, the analysis of data confirmed the Service Quality Customer Value - Customer Satisfaction - Trust/Commitment - Customer Loyalty chain for corporate customers.
\end{abstract}

Keywords: quality-value-satisfaction-loyalty chain; trust; commitment; travel agencies; industrial clients

Citation: Granados, J.C., Pérez, L.M., Pedraza-Rodríguez, J.A. and Gallarza, M. (2021). Revisiting the quality-valuesatisfaction-loyalty chain for corporate customers in the travel agency sector. European Journal of Tourism Research 27, 2711. 


\section{Introduction}

Nowadays traditional travel agencies operate in a complex, dynamic, and uncertain environment that is increasingly competitive (Aguiar et al., 2016). Consequently, the results of travel agencies depend on their abilities to provide higher value-added services and capture market loyalty (Lewis et al., 1998). Literature analyses the relationships of travel agencies with their customers, but it focuses on the relationships with end customers (e.g. Lai, 2014; Moliner et al., 2007a, 2007b; Sánchez et al., 2006). Although most travel agencies offer their services also to corporate customers, that is, to other companies that do business travel, to our knowledge no research analyses the relationships of travel agents with this type of customers in $\mathrm{B}_{2} \mathrm{~B}$ contexts.

The $\mathrm{B}_{2} \mathrm{~B}$ context, and in particular the services that travel agencies offer to corporate clients, has a series of characteristics that distinguish it from $\mathrm{B}_{2} \mathrm{C}$. More precisely, the characteristics of $\mathrm{B}_{2} \mathrm{~B}$ include: a small number of customers, service encounters that tend to be more frequent and customized (Narayandas, 2005), more professional personal interaction with enhanced technology support (Hooks \& Higgs, 2002), closer and deeper interfaces (Mehta \& Durvasula, 1998), and customers providing significant value to the global business (McNamara, 1972). Moreover, and unlike end customers, corporate customers tend to be guided mainly by rational criteria due to the complexity of decision-making processes on purchase agreements, which sometimes may be very large, and pressure from the purchasing department or organizational objectives of the company (Corsaro \& Snehota, 2010; Flint et al., 2002).

This paper aims at revisiting a well-established postulate from the $\mathrm{B}_{2} \mathrm{C}$ literature in tourism: the Quality-Value-Satisfaction-Loyalty (Q-V-S-L) chain. Moreover, this paper also aims at testing its applicability in a $\mathrm{B}_{2} \mathrm{~B}$ environment, and more specifically in the relationship between traditional travel agencies and corporate clients. For this purpose, new mediating variables between Satisfaction and Loyalty are added: Trust and Commitment, two variables of historical (Anderson, 1995; Morgan \& Hunt, 1994) and continuous consensus (Ferro et al., 2016) in industrial marketing in terms of its importance to the success of a relationship (Berry, 2002). This way, the construction of Loyalty towards the corporate client of a travel agency is proposed as a concatenation of key variables in the relationship between companies.

There is a broad consensus on the Q-V-S-L chain (Boksberger \& Melsen, 2011; Cronin et al., 2000; Gallarza et al., 2011) in the literature on consumer behaviour $\left(\mathrm{B}_{2} \mathrm{C}\right)$. As the reviews by Gallarza et al. (2017) and Oh and Kim (2017) show, this chain has also been widely tested in tourism. The initial effects of high perceived quality (efficiency, accessibility, reliability) impact on the perceived value of the relationship. This also results in higher customer satisfaction, which finally leads to greater loyalty (expressed as a predisposition to repurchase and recommendation).

Given the uniqueness of the $\mathrm{B}_{2} \mathrm{~B}$ context with respect to the $\mathrm{B}_{2} \mathrm{C}$ context, this $\mathrm{Q}-\mathrm{V}-\mathrm{S}-\mathrm{L}$ chain, in addition to including Trust and Commitment as variables mediating between Satisfaction and Loyalty, in the corporate market could present other differences with respect to consumer markets. The literature on $\mathrm{B} 2 \mathrm{~B}$ relationships recognizes the interactions among Quality, Value, Satisfaction, Trust, Commitment, and Loyalty for corporate customers. Nevertheless, to our knowledge, these interactions have not been verified as a chain of effects. B2B literature highlights that Quality influences Value (Jayawardhena, 2010; Roy et al., 2019), Value influences on Satisfaction (Eggert \& Ulaga, 2002; Lam et al., 2004; RuizMolina et al., 2015), and Satisfaction influences Loyalty (Lee et al., 2019; Lam et al., 2004). Furthermore, B2B literature suggests that Trust and Commitment are key mediators between Satisfaction and Loyalty 
(Chumpitaz \& Paparoidamis, 2007), and also indicates that Trust influences Commitment (Chumpitaz \& Paparoidamis, 2007; Morgan \& Hunt, 1994).

On the other hand, and considering the aforementioned disagreement in $\mathrm{B}_{2} \mathrm{C}$ and $\mathrm{B}_{2} \mathrm{~B}$ literature regarding Value (Mencarelli \& Rivière, 2015) in the context of retailing (Dant \& Brown, 2008), this paper tries to respond to the needs of research that consider B2B relationships as areas of key interest for the coming decades (Krafft et al., 2015; Watson et al., 2015).

According to the literature review, a research model was developed. The following hypotheses $(\mathrm{H})$ were established (Figure 1):

H1: Service Quality directly and positively affects Customer Value of corporate customers of travel agencies

H2: Customer Value directly and positively affects Customer Satisfaction of corporate customers of travel agencies

$\mathrm{H}_{3}($ a): Customer Satisfaction directly and positively affects Trust for corporate customers of travel agencies

$\mathrm{H}_{3}$ (b): Customer Satisfaction directly and positively affects Commitment of corporate customers of travel agencies

$\mathrm{H}_{4}$ : Trust directly and positively affects Commitment for corporate customers of travel agencies $H_{5}$ (a): Trust directly and positively affects Customer Loyalty of corporate customers of travel agencies $H_{5}(b)$ : Commitment directly and positively affects Customer Loyalty of corporate customers of travel agencies

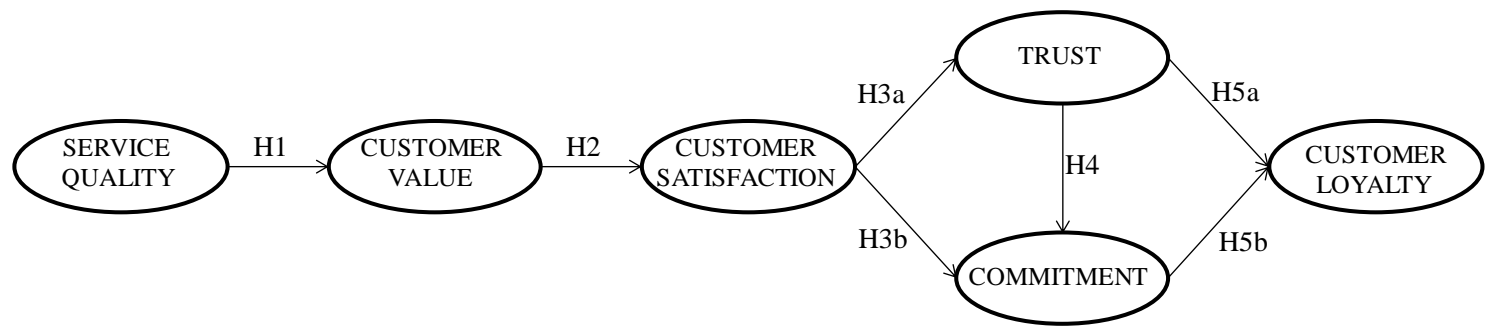

Figure 1. Research Model

This study aims at increasing our understanding of the chain of effects that determine customer loyalty in the context of travel agents and corporate customers. Moreover, the results may help provide traditional travel agencies with recommendations. Travel agencies could, therefore, use these recommendations to develop more appropriate marketing strategies to maintain a strong customer base.

\section{Method}

A survey was conducted for corporate customers of one of the largest travel agencies in Spain. Spain was chosen as this country has the most competitive tourism industry in the world according to the latest Travel \& Tourism Competitiveness Index from the World Economic Forum (2017).

The questionnaire was designed using scales adapted from previous studies in tourism services and $\mathrm{B}_{2} \mathrm{~B}$ contexts. The scale of Service Quality was adapted from the scale proposed by Sánchez et al. (2006) to be used in the purchase of a package tour at a travel agency. The scale of Value was adapted from Gallarza and Gil-Saura (2006). Regarding the measurement of Satisfaction, the items proposed here 
were adapted from Cronin et al. (2000). Trust and Commitment scales were adapted from Ferro et al. (2016). Finally, Loyalty was measured with the 5 -item scale by Zeithaml et al. (1996). All items were measured using a 5-point Likert scale. Classification variables were included at the end of the questionnaire.

In winter 2019, initial telephone contact was made using a data panel of 120 corporate customers from the chosen travel agency, offering them the possibility of completing the survey either by phone or online. Finally, 51 questionnaires were returned, achieving a response rate of $43.22 \%$. In all the cases, the respondent was the person responsible for the decision to hire the services of the travel agency.

The sample was quite balanced with regard to gender: 50.98\% were men (Table 1 ).

Table 1. Sample's Characteristics

\begin{tabular}{|c|c|c|c|c|c|}
\hline Gender & $\mathbf{n}$ & $\%$ & Turnover & $\mathbf{N}$ & $\%$ \\
\hline Male & 26 & 50.98 & Up to $1,000,000 €$ & 11 & 21.57 \\
\hline Female & 25 & 49.02 & $1,000,001 €$ to $3,000,000 €$ & 4 & 7.84 \\
\hline Age & $\mathbf{n}$ & $\%$ & $3,000,001 €$ to $6,000,000 €$ & 4 & 7.84 \\
\hline Less 25 years & 1 & 1.96 & $6,000,000 €$ to $10,000,000 €$ & 1 & 1.96 \\
\hline 25 to 35 years & 5 & 9.80 & $10,000,001 €$ to $15,000,000 €$ & 1 & 1.96 \\
\hline 36 to 40 years & 5 & 9.80 & $15,000,000 €$ to $20,000,000 €$ & 1 & 1.96 \\
\hline 41 to 45 years & 14 & 27.45 & $20,000,001 €$ and over & 16 & 31.37 \\
\hline 46 to 50 years & 16 & 31.37 & Don't know / did not answer & 13 & 25.49 \\
\hline 51 to 55 years & 8 & 15.69 & Travel management department & $\mathbf{N}$ & $\%$ \\
\hline 56 to 60 years & 2 & 3.92 & No & 30 & 58.82 \\
\hline Sector & $\mathbf{n}$ & $\%$ & Yes & 20 & 39.22 \\
\hline Manufacturing & 7 & 13.73 & Don't know / did not answer & 1 & 1.96 \\
\hline Agriculture & 6 & 11.76 & Agency XYZ as the main supplier & $\mathbf{N}$ & $\%$ \\
\hline Food and Beverages & 3 & 5.88 & No & 3 & 5.88 \\
\hline Construction & 3 & 5.88 & Yes & 45 & 88.24 \\
\hline Consultancy & 3 & 5.88 & Don`t know / did not answer & 3 & 5.88 \\
\hline Education & 3 & 5.88 & Time hiring with agency XYZ & $\mathbf{N}$ & $\%$ \\
\hline Electronics & 2 & 3.92 & Less than a year & 2 & 3.92 \\
\hline Leisure & 2 & 3.92 & 1 to 2 years & 3 & 5.88 \\
\hline Chemical & 2 & 3.92 & 3 to 5 years & 14 & 27.45 \\
\hline Health & 2 & 3.92 & 6 to 10 years & 9 & 17.65 \\
\hline Services & 2 & 3.92 & More than 10 years & 20 & 39.22 \\
\hline Telecommunications & 2 & 3.92 & Don't know / did not answer & 3 & 5.88 \\
\hline Others & 14 & $27 \cdot 44$ & Contact frequency with agency XYZ & $\mathbf{N}$ & $\%$ \\
\hline Number of workers & $\mathbf{n}$ & $\%$ & Once a year & o & 0.00 \\
\hline 1 and 5 workers & 4 & 7.84 & Once each six months & 1 & 1.96 \\
\hline 6 and 10 workers & 2 & 3.92 & Once each three months & 4 & 7.84 \\
\hline 11 and 20 workers & 5 & 9.80 & Once a month & 4 & 7.84 \\
\hline 21 and 50 workers & 6 & 11.76 & Once a week & 10 & 19.61 \\
\hline 51 and 100 workers & 7 & 13.73 & Daily & 30 & 58.82 \\
\hline More than 100 workers & 27 & 52.94 & Don`t know / did not answer & 2 & 3.90 \\
\hline
\end{tabular}

The age range of the majority of respondents was $41-50$ years $(58.82 \%)$ and belonged to companies from very different sectors. In general, these companies had more than 100 workers (52.94\%), and among those that provided information on the turnover level, the majority (60.53\%) had revenues of more than 
$€ 3$ million. Moreover, in most cases, the selected travel agency was the main provider of agency services (88.24\%), the company has been hiring products or services through this travel agency for more than 5 years $(56.87 \%)$, and the contact with the travel agency to hire their products or services occurred on a daily basis $(58.82 \%)$.

\section{Results}

As Anderson and Gerbing (1988) suggest, a two-step procedure was used to test the model: measurement model and structural model.

\section{Measurement Model}

The reliability of the indicators was confirmed, showing loading values greater than the threshold value of 0.707 (Table 2). The composite reliability, with values greater than o.70, confirmed the internal consistency of each construct. Moreover, Cronbach's Alpha also showed values above the threshold value of 0.7. Convergent validity was confirmed with values of average variance extracted (AVE) greater than 0.5. Finally, AVE square root for each construct was greater than its correlations with other constructs, and discriminant validity was confirmed.

\section{Structural Model}

Figure 2 shows the results of the structural evaluation. All the endogenous constructs of the model, with $\mathrm{R}^{2}$ values ranging from 0.220 to 0.490 , show acceptable predictive levels. The proposed model explains $49 \%$ of the variance of Customer Loyalty. According to the path significance analysis, all hypotheses are supported.

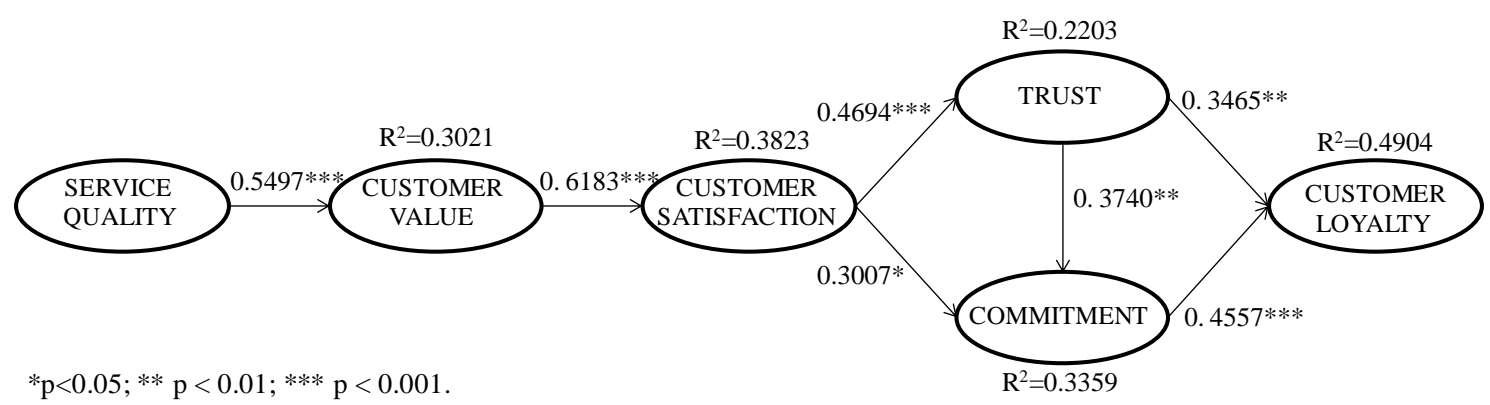

Figure 2. Results of the PLS Analysis

Our results confirm the Q-V-S-Trust/Commitment-L chain in a $\mathrm{B}_{2} \mathrm{~B}$ environment. The strongest link is between Value and Satisfaction (0.6183, p<0.001), followed by the link between Quality and Value (o.5497, p<0.001). Moreover, the S-Trust/Commitment-L chain shows pretty balanced links. More specifically, the link between Satisfaction and Trust (0.4694, $\mathrm{p}<0.001)$ is slightly stronger than the link between Satisfaction and Commitment (0.3007, p<0.05). However, the link between Trust and Loyalty (o.3465, p<0.01) is slightly weaker than the link between Commitment and Loyalty (0.4557, p<0.001). In this case, it is necessary to consider that Trust significantly influences Commitment (0.374, $\mathrm{p}<0.01)$. 
Table 2. Assessment of the Measurement Model

\begin{tabular}{|c|c|c|c|c|c|c|}
\hline Factor & Mean & $\begin{array}{l}\text { Standard } \\
\text { Deviation }\end{array}$ & Loading & Cronbach's $\alpha$ & $\begin{array}{l}\text { Composite } \\
\text { Reliability }\end{array}$ & AVE \\
\hline SERVICE QUALITY & & & & 0.829 & 0.887 & 0.660 \\
\hline $\begin{array}{l}\text { The products or services purchased } \\
\text { were well organised }\end{array}$ & 4.64 & 0.480 & 0.785 & & & \\
\hline $\begin{array}{l}\text { Relative to products or services } \\
\text { provided by other agencies had an } \\
\text { acceptable level of quality }\end{array}$ & 4.68 & 0.466 & 0.757 & & & \\
\hline $\begin{array}{l}\text { The quality of the services provided } \\
\text { by XYZ was maintained throughout }\end{array}$ & 4.62 & 0.485 & 0.846 & & & \\
\hline The result was as expected & 4.70 & 0.500 & 0.856 & & & \\
\hline CUSTOMER VALUE & & & & 0.888 & 0.931 & 0.817 \\
\hline $\begin{array}{l}\text { Overall, the value of the services } \\
\text { provided by XYZ is adequate }\end{array}$ & 4.48 & 0.500 & 0.897 & & & \\
\hline $\begin{array}{l}\text { I consider that my experience with } \\
\text { the services of XYZ is good comparing } \\
\text { what I gave up and what I received }\end{array}$ & 4.50 & 0.608 & 0.909 & & & \\
\hline $\begin{array}{l}\text { The experience with XYZ has satisfied } \\
\text { my needs and wants }\end{array}$ & 4.56 & 0.535 & 0.906 & & & \\
\hline CUSTOMER SATISFACTION & & & & 0.920 & 0.950 & 0.862 \\
\hline $\begin{array}{l}\text { My choice to purchase in XYZ has } \\
\text { been a wise one. }\end{array}$ & $4 \cdot 52$ & 0.538 & 0.930 & & & \\
\hline $\begin{array}{l}\text { I did the right thing when I purchased } \\
\text { at XYZ }\end{array}$ & 4.50 & 0.539 & 0.942 & & & \\
\hline $\begin{array}{l}\text { The experience with XYZ has been } \\
\text { exactly what I needed }\end{array}$ & 4.50 & 0.539 & 0.913 & & & \\
\hline TRUST & & & & 0.771 & 0.869 & 0.689 \\
\hline $\begin{array}{l}\text { I can rely on XYZ to keep promises } \\
\text { made to me }\end{array}$ & 4.62 & 0.485 & 0.872 & & & \\
\hline $\begin{array}{l}\text { I are not hesitant to do business with } \\
\mathrm{XYZ} \text { even when the situation is vague }\end{array}$ & $4 \cdot 32$ & 0.705 & 0.744 & & & \\
\hline $\mathrm{XYZ}$ is trustworthy & 4.76 & 0.427 & 0.867 & & & \\
\hline COMMITMENT & & & & 0.952 & 0.960 & 0.912 \\
\hline $\begin{array}{l}\text { I intend to do business with XYZ well } \\
\text { into the future }\end{array}$ & 4.38 & 0.629 & 0.936 & & & \\
\hline $\begin{array}{l}\text { I am dedicated to continuing doing } \\
\text { business with XYZ }\end{array}$ & $4 \cdot 32$ & 0.676 & 0.967 & & & \\
\hline $\begin{array}{l}\text { I am resolute about my future intent } \\
\text { to do business with XYZ }\end{array}$ & 4.28 & 0.749 & 0.962 & & & \\
\hline CUSTOMER LOYALTY & & & & 0.906 & 0.931 & 0.733 \\
\hline $\begin{array}{l}\text { I say positive things about XYZ to } \\
\text { other companies }\end{array}$ & $4 \cdot 34$ & 0.651 & 0.854 & & & \\
\hline $\begin{array}{l}\text { I recommend XYZ to companies } \\
\text { seeking my advice }\end{array}$ & 4.40 & 0.600 & 0.943 & & & \\
\hline $\begin{array}{l}\text { I encourage other companies to do } \\
\text { business with XYZ }\end{array}$ & 4.16 & 0.833 & 0.918 & & & \\
\hline $\begin{array}{l}\text { I consider XYZ as my first choice to } \\
\text { purchase tourism products and } \\
\text { services }\end{array}$ & $4 \cdot 40$ & 0.721 & 0.686 & & & \\
\hline $\begin{array}{l}\text { I will do more business with XYZ in } \\
\text { the next few years }\end{array}$ & 4.38 & 0.797 & 0.855 & & & \\
\hline
\end{tabular}




\section{Conclusion}

To our knowledge, this research is one of the first studies that explore the relationship between travel agencies and their corporate customers. Moreover, and aiming at bridging the gap between literature on $\mathrm{B}_{2} \mathrm{C}$ and $\mathrm{B} 2 \mathrm{~B}$, as suggested by Mencarelly and Riviere (2015), this paper confirms empirically the Q$\mathrm{V}-\mathrm{S}$ - $\mathrm{L}$ chain using all the knowledge generated in the $\mathrm{B}_{2} \mathrm{C}$ literature in general, and particularly in the literature on tourism. However, this study adapts it to the $\mathrm{B} 2 \mathrm{~B}$ context by introducing the variables Trust and Commitment into the chain, mediating between Satisfaction and Loyalty. The literature in $\mathrm{B}_{2} \mathrm{~B}$ contexts recognizes the interactions between the variables analysed here, but to the best of our knowledge, these interactions have not been tested as a chain of effects.

Our results show that travel agencies do not only need to provide a high-quality service that results in a greater value, which also turns into greater satisfaction, but it is also necessary that travel agencies develop relationships of trust and commitment to make corporate clients more loyal.

This research has however some limitations. First, the empirical study is limited to a single company, evaluating its relationships with $\mathbf{5 1}$ clients in a single geographical area. Consequently, the results are difficult to generalize. Future research could consider expanding the analysis to other companies and regions to validate our findings. Second, the empirical study has not measured moderating effects. Future lines of research could explore the effect of variables such as the duration of the relationship or the turnover level.

\section{References}

Aguiar-Quintana, T., Moreno-Gil, S., \& Picazo-Peral, P. (2016). How could traditional travel agencies improve their competitiveness and survive? A qualitative study in Spain. Tourism Management Perspectives, 20, 98-108.

Anderson, J.C. (1995). Relationships in business markets: exchange episodes, value creation, and their empirical assessment. Journal of the Academy of Marketing Science, 23(4), 346-350.

Anderson, J.C., \& Gerbing, D.W. (1988). Structural equation modeling in practice: A review and recommended two-step approach. Psychological Bulletin, 103(3), 411-423.

Berry, L.L. (2002). Relationship marketing of services perspectives from 1983 and 20oo. Journal of Relationship Marketing, 1(1), 59-77.

Boksberger, P.E., \& Melsen, L. (2011). Perceived value: a critical examination of definitions, concepts and measures for the service industry. Journal of Services Marketing, 25(3), 229-240.

Chumpitaz, R., \& Paparoidamis, N.G. (2007). Service quality, relationship satisfaction, trust, commitment and business-to-business loyalty. European Journal of Marketing, 41(7/8), 836-867.

Corsaro, D., \& Snehota, I. (2010). Searching for Relationship Value in Business Markets: Are We Missing Something? Industrial Marketing Management, 39(6), 986-995.

Cronin, J.J., Brady, M.K., \& Hult, G.T.M. (2000). Assessing the effects of quality, value and customer satisfaction on consumer behavioural intentions in service environments. Journal of Retailing, 76(2), 193-218.

Dant, R.P., \& Brown, J.R. (2008). Bridging the $\mathrm{B}_{2} \mathrm{C}$ and $\mathrm{B}_{2} \mathrm{~B}$ research divide: the domain of retailing literature. Journal of Retailing, 84(4), 371-397.

Eggert, A., \& Ulaga, W. (2002). Customer perceived value: A substitute for satisfaction in business markets. Journal of Business and Industrial Marketing, 17(2/3), 107-118.

Ferro, C., Padin, C., Svensson, G., \& Payan, J. (2016). Trust and commitment as mediators between economic and non-economic satisfaction in manufacturer-supplier relationships. Journal of Business \& Industrial Marketing, 31(1), 13-23. 
Flint, D.J., Woodruff, R.B., \& Gardial, S.F. (2002). Exploring the phenomenon of customers' desired value change in a business-to-business context. Journal of Marketing, 66(4), 102-117.

Gallarza, M.G., \& Gil-Saura, I. (2006). Value dimensions, perceived value, satisfaction and loyalty: an investigation of university students' travel behavior. Tourism Management, 27, 437-452.

Gallarza, M.G., Gil-Saura, I., \& Holbrook, M.B. (2011). The value of value: Further excursions on the meaning and role of customer value. Journal of Consumer Behaviour, 10(4), 179-191.

Gallarza, M.G., Gil-Saura, I., \& Arteaga-Moreno, F. (2017). Exploring competing models on sacrifices, quality, value, satisfaction and loyalty with PLS and partial correlations. European Journal of Tourism Research, 17, 115-134.

Hooks, K.L., \& Higgs, J.L. (2002). Workplace Environment in a Professional Services Firm. Behavioral Research in Accounting, 14, 105-128.

Jayawardhena, C. (2010). The impact of service encounter quality in service evaluation: evidence from a business-to-business context. Journal of Business E Industrial Marketing, 25(5), 338-348.

Krafft, M., Goetz, O., Mantrala, M., Sotgiu, F., \& Tillmanns, S. (2015). The evolution of marketing channel research domains and methodologies: an integrative review and future directions. Journal of Retailing, 91(4), 569-585.

Lai, I.K.W. (2014). The role of service quality, perceived value and relationship quality in enhancing customer loyalty in the travel agency sector. Journal of Travel $\mathcal{E}$ Tourism Marketing, 31, 417-442.

Lam, S.Y., Shankar, V., Erramilli, K., \& Murthy, B. (2004). Customer value, satisfaction, loyalty, and switching cost: An illustration from a business-to-business service context. Journal of the Academy of Marketing Science, 32(3), 293-311.

Lee, M., Kang, M., \& Kang, J. (2019). Cultural influences on B2B service quality-satisfaction-loyalty. The Service Industries Journal, 39(3/4), 229-249.

Lewis, I., Semeijn, J., \& Talalayevsky, A. (1998). The impact of information technology on travel agents. Transportation Journal, 37(4), 20-25.

McNamara, C.P. (1972). The Present Status of the Marketing Concept. Journal of Marketing, 36, 50-62.

Mehta, S.C., \& Durvasula, S. (1998). Relationships between SERVQUAL Dimensions and Organizational Performance in the Case of Business-to-Business Service. Journal of Business and Industrial Marketing, 13(1), 40-55.

Mencarelli, R., \& Rivière, A. (2015). Perceived value in B2B and B2C: A comparative approach and crossfertilization. Marketing Theory, 15(2), 201-220.

Moliner, M.A., Sánchez, J., Rodríguez, R.M., \& Callarisa, L. (2007a). Travel agency relationship quality. Annals of Tourism Research, 34(2), 537-540.

Moliner, M.A., Sánchez, J., Rodríguez, R.M., \& Callarisa, L. (2007b). Relationship quality with a travel agency: The influence of the postpurchase perceived value of a tourism package. Tourism and Hospitality Research, 7(3/4), 194-211.

Morgan, R.M., \& Hunt, S.D. (1994). The commitment-trust theory of relationship marketing. Journal of Marketing, 58(3), 20-38.

Narayandas, D. (2005). Building loyalty in business markets. Harvard Business Review, 1 (September), 131-139.

Oh, H., \& Kim, K. (2017). Customer satisfaction, service quality, and customer value: years 200o-2015. International Journal of Contemporary Hospitality Management, 29(1), 2-29.

Roy, S., Sreejesh S., \& Bhatia, S. (2019). Service quality versus service experience: An empirical examination of the consequential effects in $\mathrm{B} 2 \mathrm{~B}$ services. Industrial Marketing Management, 82, $52-69$.

Ruiz-Molina, M.E., Gil-Saura, I., \& Moliner-Velázquez, B. (2015). Relational benefits, value, and satisfaction in the relationships between service companies. Journal of Relationship Marketing, $14(1), 1-15$. 
Sánchez, J., Callarisa, L., Rodríguez, R.M., \& Moliner, M.A. (2006). Perceived value of the purchase of a tourism product. Tourism Management, 27, 394-409.

Watson, G.F., Worm, S., Palmatier, R.W., \& Ganesan, S. (2015). The evolution of marketing channels: trends and research directions. Journal of Retailing, 91(4), 546-568.

World Economic Forum. (2017). The Travel \& Tourism Competitiveness Report 2017. https://www.weforum.org/reports/the-travel-tourism-competitiveness-report-2017

Zeithaml, V.A., Berry, L.L. \& Parasuraman, A. (1996). The behavioral consequences of service quality. Journal of Marketing, 6o(2), 31-46.

Received: 29/07/2020

Accepted: 04/o8/2020

Coordinating editor: Stanislav Ivanov 